\title{
Container Cargo Operation and Time Study of Container Cargo Movements in the 6D Shipping \& Logistics
}

\author{
D.S.Varsha, S Praveen kumar, Anish Paul
}

\begin{abstract}
Cargo liners had steadily improved in their speed and efficiency with the regularity and frequency of services matching the demands of steadily increasing international trade. Further improvements wore, however, hampered by the fact that general cargo came in all shapes and sizes. From massive crates of machinery to drums, bales, and cartons. Over a thousand separate consignments per sailing were not unusual and all these had to best owed by hand. Piece-to-piece cargo is now referred to as break bulk or conventional cargo. Extraordinary skill was needed to ensure that the different consignments did not damage each other and were carried safely even in heavy weather. The time taken in port was such that there was no scope for any economies of scale because larger ships meant even longer in port. The cost of building faster ships would be lost as the time in port could not be improved
\end{abstract}

Keywords : sociology, generalizability, discernments

\section{INTRODUCTION}

Cargo liners had steadily improved in their speed and efficiency with the regularity and frequency of services matching the demands of steadily increasing international trade. Further improvements wore, however, hampered by the fact that general cargo came in all shapes and sizes. From massive crates of machinery to drums, bales, and cartons. Over a thousand separate consignments per sailing were not unusual and all these had to best owed by hand. Piece-to-piece cargo is now referred to as break bulk or conventional cargo. Extraordinary skill was needed to ensure that the different consignments did not damage each other and were carried safely even in heavy weather. The time taken in port was such that there was no scope for any economies of scale because larger ships meant even longer in port. The cost of building faster ships would be lost as the time in port could not be improved. [8],[ 10] ,[12]

Revised Manuscript Received on July 22, 2019.

D.S.Varsha, Department of MBA,Bharath institute of Higher Education \& Research,Tamilnadu,India Email:varsha@gmail.com

Dr S Praveen kumar Director, Department of MBA,Bharath institute of Higher Education \& Research, Tamilnadu, India Email:praveenkumar.mba@bharathuniv.ac.in

Anish Paul, Department of Civil,,Bharath institute of Higher Education \& Research,Tamilnadu,India Email: anishdavidpaul@gmail.com

Santhamoorthy.M，2008Freight forwarding companies should hire professionals who have expertise in packaging, labeling and palletizing corresponding to products. Company needs well organized departments to take care of customer's problems[19],[21],[23]

Pierre David, Ph.D. Baldwin - Wallace Collegein addition to the risk of a shipment by ocean, there is also the possibility of damage caused by other cargo in the container: a heavy load can inadvertently be placed on top of pallet, or it can be subjected to leakage, odors, and other hazards. Proper stowage plan is necessary to ensure reducing the damage[19],[21],[23]

Krishnaveni Muthaiah.R, 1999LCL consolidators and Non vessel operating common carriers need to have extensive range of contacts to Survive in this business. Consolidating is a complex activity which requires good packaging knowledge to arrange and consolidate packages without any damage[7],[9] ,[11]

\section{OBJECTIVES}

- To analyze the timely \& lead periods involved in movement of container from the point of consumption.

- To track \& keep up with the updated information regarding container $\&$ cargo for the customers.

- To evolve efficiency in the movements of same with effective stipulations of newer innovative ideas \& structured movements.

- To study the type of container for the requirement cargoes offered. [1],[3],[5]

\section{RESEARCH METHODOLOGY}

The system of collecting data for research projects is known as research methodology. The data may be collected for either theoretical or practical research for example management research may be strategically conceptualized along with operational planning methods and change management., Sample size of my survey is 50 customers ,which is organized carefully into graphs and tables so that only important relevant data is shown.

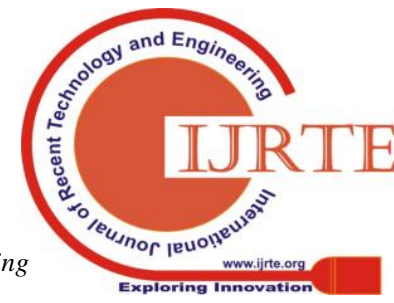


Research methodology means the method carried out to study the problem, it shows the type of the sample design used, its size and the procedure used to dew sample. [13], [15] ,[ 17]

\section{RESULTS \& DISCUSSION}

$1.36 \%$ customers are satisfied. $36 \%$ customers are highly satisfied with the tariff rates.as well $2 \%$ customers are dissatisfied with the tariff rates. [25],[27],[29]

2. $38 \%$ customers are satisfied and $32 \%$ customers are highly satisfied with the cargo handling services but none of the customers are dissatisfied with the cargo handling services.

3 . $32 \%$ of the customers found dent or damages, $52 \%$ of the customers found strain marks in the containers while receiving. And $16 \%$ of the on the containers in the receiving point[2 ],[4],[6]

4. $28 \%$ of the customer's container issues are sent for repair. $68 \%$ say to inform to equipment controller as an immediate action taken for the containers.

5. $42 \%$ customer's feels General Containers $24 \%$ customer's for Reefer Containers have high demand in the market. $12 \%$ customer's go for Flat Track Containers have high demand in the market. 16\% customer's for Open top Containers have high demand in the market[14],[16], [18]

\section{CONCLUSION}

Container cargo operation study dealt with the types of container required to different types of cargoes and the demand for the customers such as tracking system service level and the service according to the satisfaction level of the customers are studied and tariff level are accordingly revised according to the service demanded by the customers and stuffing of the cargo accordingly and charges for such services are analyzed in the above study. [26],[28],[30]

\section{REFERENCES}

1) BharthVajan R., Ramachandran S.,Psychographic dimensions of training,2016, International Journal of Pharmacy and Technology,V-8,I-4,P-23727-23729

2) Balakrishnan P., Bharthvajan R.,A study on human resource planning in hospitals in Chennai City,2014,International Journal of Applied Engineering Research,V-9,I-22,P-7503-7507

3) Priyadarsini P., Bharthvajan R.,Role of emotional intelligence training programme in reducing the stress of the nurses,2014,International Journal of Applied Engineering Research,V-9,I-22,P-7411-7421

4) Kerinab Beenu G., Bharthvajan R.,Empirical analysis on the cosmetic buying behavior of young women in South India,2014,International Journal of Applied Engineering Research,V-9,I-22,P-7361-7366

5) Balakrishnan P., Bharthvajan R.,Whistling in the wind,2014,International Journal of Applied Engineering Research,V-9,I-22,P-7586-7593

6) Krishnan B., Peter M.,Health hazards of Indian Bpo employee-an alarming issue,2014,International Journal of Applied Engineering Research,V-9,I-22,P-7336-7341

7) Kerinab Beenu G.H., Peter M.,Role of insurance in economic development,2014,International Journal of Applied Engineering Research,V-9,I-22,P-7532-7539

8) Balakrishnan P., Peter M., Priyadarsini P.,Efficiency of safety measures for wellbeing of employees in manufacturing industry,2014,International Journal of Applied Engineering Research,V-9,I-22,P-7376-7382

9) Anbarasi M., Praveen Kumar S.,Online sales promotions of herbal products and its effectiveness towards tanisha.com,2019,Indian Journal of Public Health Research and Development,V-10,I-1,P-195-200

10) Anbarasi M., Praveen Kumar S., Various online marketing and promotions strategies to improve the validation towards the organic products in the pharmaceutical sectors,2019,Indian Journal of Public Health Research and Development, V-10,I-1,P-263-269

11) Loganathan R., Praveen Kumar S.,Grievance handling a key factor for solving issues of employees in an organization,2014,International Journal of Applied Engineering Research,V-9,I-22,P-7483-7491
12) Loganathan R., Praveen Kumar S.,Study on preference of private label brands in super and Hypermarkets,2014,International Journal of Applied Engineering Research,V-9,I-22,P-7327-7335

13) Smitha M., Praveen Kumar S.,Understanding stress and its managementamong the nurses in Chennai city,2014,International Journal of Applied Engineering Research,V-9,I-22,P-7560-7565

14) Kerinab Beenu G.H., Praveen Kumar S.,A study on the investment behavior of Chennai investors in mutual fund schemes,2014,International Journal of Applied Engineering Research,V-9,I-22,P-7520-7525

15) Loganathan R., Praveen Kumar S.,Retention strategies key for organizational productivity,2014,International Journal of Applied Engineering Research,V-9,I-22,P-7443-7447

16) Pavithra J., Ganesan M., Brindha G.,State wise analysis of microfinance sector in India,2016, International Journal of Pharmacy and Technology,V-8,I-4,P-23417-23432

17) Pavithra J., Ganesan M.,A comparative study on microfinance in India and abroad,2016,International Journal of Applied Business and Economic Research,V-14,I-8,P-5471-5476

18) Pavithra J., Ganesan M.,A study on awareness and impact of micro-financial schemes,2016,International Journal of Applied Business and Economic Research,V-14,I-8,P-5449-5460

19) Senthilmurugan P., Pavithra J.,Consumer preference towards organised retailing with reference to Big Bazaar,2014,International Journal of Applied Engineering Research,V-9,I-22,P-7469-7475

20) Senthilmurugan P., Pavithra J.,Implication of social media marketing in growing healthcare industry,2014,International Journal of Applied Engineering Research,V-9,I-22,P-7448-7456

21) Loganathan R., Pavithra J.,Consumer perception towards private label brand over other brands in super markets and hypermarkets,2014,International Journal of Applied Engineering Research,V-9,I-22,P-7355-7360

22) Kerinab Beenu G., Pavithra J.,Tradeâ€"off between liquidity and profitability in logistics industry,2014,International Journal of Applied Engineering Research,V-9,I-22,P-7398-7401

23) Kerinab Beenu G., Pavithra J.,A study on the prospective consumerâ€ $\mathrm{TM}_{\mathrm{S}}$ perception towards utility cars in Chennai city,2014,International Journal of Applied Engineering Research,V-9,I-22,P-7526-7531

24) Pavithra J., Dilli Babu P., Ambuli T.V.,A study on budgetary control at Maruti Service Masters, Chennai,2014,International Journal of Applied Business and Economic Research,V-12,I-2,P-151-161

25) Pavithra J., Dilli Babu P., Ambuli T.V.,A study on customer satisfaction of retro Garments Pvt Ltd, Chennai,2014,International Journal of Applied Business and Economic Research,V-12,I-2,P-381-391

26) Kerinab Beenu G.H., Pavithra J., Senthilmurugan P.,A study on the influence of promotional activities for TATA ARIA among consumers in Chennai,2014,International Journal of Applied Engineering Research,V-9,I-22,P-7572-7578

27) Vijayaragavan S.P.,An investigative expert that's general FBG sensors,International Journal of Mechanical Engineering and Technology,V-8,I-8,PP-1500-1505,Y-2017

28) Vijayaragavan S.P.,Equalization routing protocol for Wi-Fi sensor strategy,International Journal of Mechanical Engineering and Technology,V-8,I-8,PP-1662-1666,Y-2017

29) Karthik B., Kiran Kumar T.V.U., Vijayaragavan P., Bharath Kumaran E.,Design of a digital PLL using 0.35 1̂1/4m CMOS technology,Middle East Journal of Scientific Research,V-18,I-12,PP-1803-1806,Y-2013

30) Kanniga E., Selvaramarathnam K., Sundararajan M.,Kandigital bike operating system,Middle - East Journal of Scientific Research,V

31) Jasmin M., Vigneshwaran T., Beulah Hemalatha S.,Design of power aware on chip embedded memory based FSM encoding in FPGA,International Journal of Applied Engineering Research,V-10,I-2,PP-4487-4496,Y-2015

32) Jasmin M.,Optimization techniques for low power VLSI circuits,Middle East Journal of Scientific Research,V-20,I-9,PP-1082-1087,Y-2014

33) Jasmin M., Vigneswaran T.,Fuzzy controller for error control of on - Chip communication,2017 International Conference on Algorithms, Methodology, Models and Applications in Emerging Technologies, ICAMMAET 2017,V-2017-January,I-,PP-1-5,Y-2017 


\section{AUTHORS PROFILE}

D.S.Varsha ,Student Department of MBA,Bharath institute of Higher Education \& Research, Tamilnadu, India

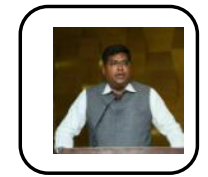

Second Author Dr S Praveen kumar Director, Department of MBA, Bharath institute of Higher Education \& Research,Tamilnadu,India

Anish Paul Assistant ProfessorDepartment of Civil,,Bharath institute of Higher Education \& Research, Tamilnadu, India Email: anishdavidpaul@gmail.com 